\title{
Antiplasmodial phloroglucinol derivatives from Syncarpia glomulifera
}

\author{
Qingxi Su ${ }^{\mathrm{a}}$, Seema Dalal ${ }^{\mathrm{b}}$, Michael Goetz ${ }^{\mathrm{c}}$, Maria B. Cassera ${ }^{\mathrm{b}}$, David G. I. Kingston ${ }^{\mathrm{a}}{ }^{*}$
}

${ }^{a}$ Department of Chemistry and Virginia Tech Center for Drug Discovery, Virginia Tech, Blacksburg, Virginia 24061, United States

${ }^{\mathrm{b}}$ Department of Biochemistry and Virginia Tech Center for Drug Discovery, Virginia Tech, Blacksburg, Virginia 24061, United States

${ }^{\mathrm{c}}$ Natural Products Discovery Institute, Doylestown, Pennsylvania 18902, United States

\section{ABSTRACT}

Bioassay guided fractionation of a $\mathrm{MeOH}$ extract of the stem bark of Syncarpia glomulifera (Myrtaceae) led to the isolation of the two new phloroglucinol derivatives ( \pm )-rhodomyrtosone $\mathrm{F}$ (1) and ( \pm )-calliviminone $C(\mathbf{2})$, the three known triterpenes, betulinic acid (3), ursolic acid-3acetate (4), and ursolic acid (5), and 1-(2,4,6-trihydroxyphenyl)-1-hexanone (6). Compound 1 exhibited strong antiplasmodial activity, while compounds $\mathbf{2}$ - $\mathbf{4}$ were moderately active and $\mathbf{5}$ and $\mathbf{6}$ were inactive in this assay. The structures of $\mathbf{1}$ and $\mathbf{2}$ were elucidated based on analyses of their mass spectrometric data, 1D and 2D NMR spectra, and comparison with related compounds.

Keywords: Antiplasmodial activity, Phloroglucinol, Syncarpia glomulifera (Myrtaceae

\footnotetext{
* Corresponding author: Tel: +1 540231 6570: fax: +1-540 231 3255. E-mail address: dkingston@ vt.edu
} 


\section{Introduction}

Malaria is a life threatening disease that has afflicted human beings for thousands of years, with references to periodic fevers as far back as $2700 \mathrm{BC}$ in China. ${ }^{1}$ The disease is caused by protozoan parasites of the Plasmodium genus and transmitted by mosquitoes infected with these parasites. $^{2}$ More than 200 million people are estimated to be infected with malaria every year, and over 400,000 of them die, with women and children being the most vulnerable. ${ }^{3-4}$ One of the major families of antimalarial drugs is based on chloroquine, but chloroquine resistant $P$. falciparum (the deadliest of the five species that infect humans) has been detected since the 1950s in Southeast Asia and South America, ${ }^{5-6}$ and resistance has developed to nearly all of the other currently available antimalarial drugs, such as sulfadoxine/pyrimethamine, mefloquine, halofantrine, and quinine. ${ }^{7}$ The most effective current treatments are artemisinin-based combination therapies (ACTs). Unfortunately, resistance against artemisinin was reported on the Thai-Cambodian border in 2009, where it has been used for more than 20 years. ${ }^{8}$ Because antimalarial resistance can emerge quickly, it is critical to have new drugs with novel mechanisms of action in the antimalarial pipeline.

In pursuit of this goal, we obtained a $\mathrm{MeOH}$ extract from the stem bark of a Hawaiian specimen of Syncarpia glomulifera (Myrtaceae). The extract was selected for investigation based on its antiplasmodial activity against the Dd2 drug-resistant strain of $P$. falciparum. Previous studies have reported the isolation of antibacterial and cytotoxic triterpenoids from the bark extract of $S$. glomulifera from Paluma, North Queensland, Australia. ${ }^{9}$ However, no work has been reported on the isolation of any antimalarial agent from this species. 
We describe herein the isolation, structure elucidation and antiplasmodial activity of two new phloroglucinols, named as ( \pm )-rhodomyrtosone $\mathrm{F}(\mathbf{1})$ and $( \pm)$-calliviminone $\mathrm{C}(\mathbf{2})$, along with four known compounds (Fig. 1).

\section{Results and Discussion}

Bioassay guided fractionation of an extract of the stem bark of S. glomulifera yielded the four known compounds betulinic acid (3), ${ }^{10}$ ursolic acid-3-acetate (4), ${ }^{11}$ ursolic acid (5), ${ }^{11}$ and 1 (2,4,6-trihydroxyphenyl)-1-hexanone (6), ${ }^{12}$ and the two new phloroglucinol derivatives 1 and 2. The structures of compounds 3-6 were identified by comparison of their ${ }^{1} \mathrm{H}$ NMR and mass spectrometric data with literature data. ${ }^{10-12}$ The structures of $\mathbf{1}$ and $\mathbf{2}$ were elucidated by interpretation of mass spectrometric and NMR data as described below. Compound 1 showed strong antimalarial activity, while compounds 2-4 showed moderate to weak antimalarial activity against the Dd2 drug-resistant strain of Plasmodium falciparum. Compounds $\mathbf{5}$ and $\mathbf{6}$ were inactive at 40 and $80 \mu \mathrm{M}$, respectively, in this assay. 


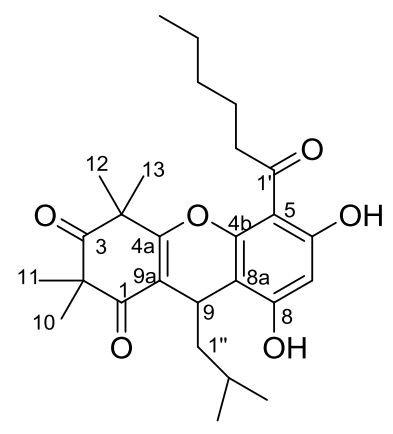

1 ( \pm )-rhodomyrtosone $\mathrm{F}$

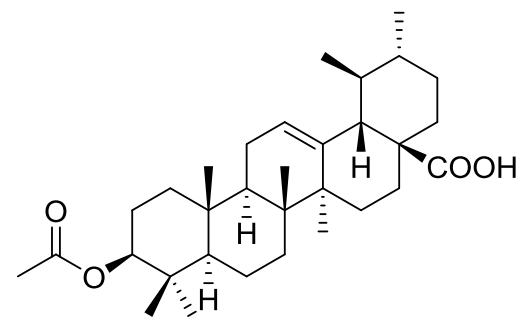

4 ursolic acid-3-acetate

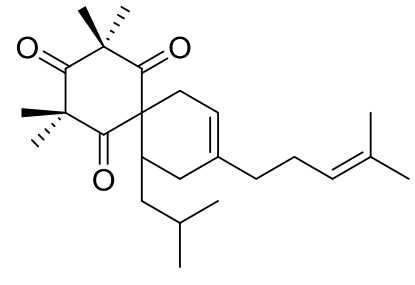

$2( \pm)$-calliviminone C

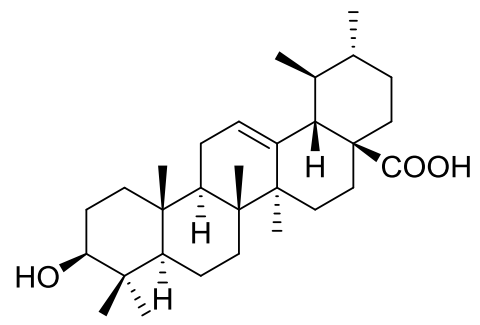

5 ursolic acid

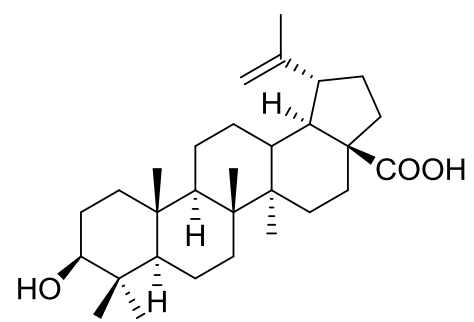

3 betulinic acid

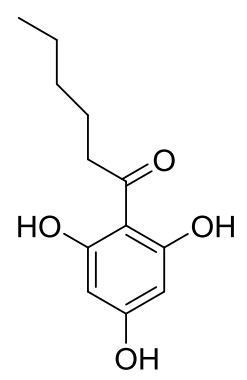

6 1-(2,4,6-trihydroxyphenyl)1-hexanone

Figure 1. Structures of compounds from Syncarpia glomulifera

Compound 1 was isolated as a yellowish gum. The protonated molecule peak at $\mathrm{m} / \mathrm{z} 457.2591$ $[\mathrm{M}+\mathrm{H}]^{+}$(calcd for $\mathrm{C}_{27} \mathrm{H}_{37} \mathrm{O}_{6}^{+}$, 457.2585) suggested a molecular formula of $\mathrm{C}_{27} \mathrm{H}_{36} \mathrm{O}_{6}$ with 10 degrees of unsaturation. The ${ }^{1} \mathrm{H}$ NMR, ${ }^{13} \mathrm{C}$ NMR and HSQC spectra (Table 1) indicated the presence of 3 carbonyl, 9 quaternary, 3 methine, 5 methylene and 7 methyl carbons in the structure. The cyclohexene-1,3-dione moiety of compound 1 was suggested by HMBC correlations of 10and 11-Me $\left(\delta_{\mathrm{H}} 1.36\right.$ and 1.39, each $\left.3 \mathrm{H}, \mathrm{s}\right)$ to $\mathrm{C}-1, \mathrm{C} 2$ and $\mathrm{C}-3\left(\delta_{\mathrm{C}} 197.6,56.2\right.$ and 212.3), and of 12- and 13-Me $\left(\delta_{\mathrm{H}} 1.43\right.$ and 1.54 , each $3 \mathrm{H}$, s) to $\mathrm{C}-3, \mathrm{C}-4\left(\delta_{\mathrm{C}} 47.3\right)$ and $\mathrm{C}-4 \mathrm{a}\left(\delta_{\mathrm{C}} 166.9\right)$. In addition $\mathrm{H}-9\left(\delta_{\mathrm{H}} 4.24, \mathrm{~d}, J=5.6 \mathrm{~Hz}\right)$ correlated to C-1, C-9a $\left(\delta_{\mathrm{C}} 114.3\right)$ and C-4a $\left(\delta_{\mathrm{C}} 166.9\right)$. An aromatic ring was assigned to connect to C-9 due to the deshielded chemical shift of H-9 along 
with HMBC correlations of $\mathrm{H}-9$ to $\mathrm{C}-4 \mathrm{~b}, \mathrm{C}-8 \mathrm{a}$ and $\mathrm{C}-8\left(\delta_{\mathrm{C}} 162.6,106.9\right.$ and 155.8$)$. The placement of the aromatic proton $\mathrm{H}-7$ was determined based on its HMBC correlations with C-8a, C-8 and C$6\left(\delta_{\mathrm{C}} 158.5\right) . \mathrm{C}-4 \mathrm{a}, \mathrm{C}-4 \mathrm{~b}, \mathrm{C}-6, \mathrm{C}-8$ were oxygenated due to their low field signals $\left(\delta_{\mathrm{C}} 155.8 \sim 166.9\right)$. The identifications and placements of the acyl and isobutyl groups were confirmed by COSY and HMBC correlations (Fig. 2) along with comparison of NMR data with those of related compounds. ${ }^{13-14}$ An oxygen atom was assigned to connect C-4a and C-4b to give a tricyclic skeleton, based on the ${ }^{13} \mathrm{C}$ NMR signals of $\mathrm{C}-4 \mathrm{a}$ and $\mathrm{C}-4 \mathrm{~b}$, and on the degree of unsaturation.

Compound $\mathbf{1}$ had an optical rotation of zero, indicating that it was isolated as a racemate. It was thus assigned the structure ( \pm )-4,9-dihydro-6,8-dihydroxy-2,2,4,4-tetramethyl-5-hexanoyl-9isobutyl-1H-xanthene-1,3(2H)-dione and named as $( \pm)$-rhodomyrtosone $\mathrm{F}$ based on its similarity to rhodomyrtone ${ }^{15}$ and rhodomyrtosones $\mathrm{B}^{14}$ and $\mathrm{E}^{16}$

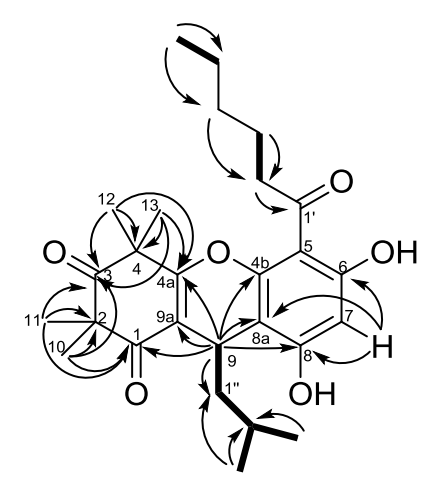

HMBC

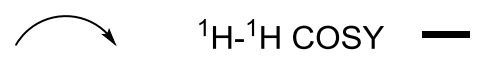

Figure 2. Key HMBC and COSY correlations of compound $\mathbf{1 .}$ 
Table 1. ${ }^{1} \mathrm{H}$ and ${ }^{13} \mathrm{C}$ NMR Data ( $\delta$, ppm) for compounds $\mathbf{1}$ and $2(500$ and $125 \mathrm{MHz})$ in $\mathrm{CDCl}_{3}$

\begin{tabular}{|c|c|c|c|c|c|}
\hline \multirow[b]{2}{*}{ Position } & \multicolumn{2}{|c|}{1} & \multirow[b]{2}{*}{ Position } & \multicolumn{2}{|l|}{2} \\
\hline & $\delta_{\mathrm{H}},(J \text { in } \mathrm{Hz})^{\mathrm{a}}$ & $\delta_{\mathrm{C}}$, type $^{\mathrm{b}}$ & & $\delta_{\mathrm{H}},(J \text { in } \mathrm{Hz})^{\mathrm{a}}$ & $\delta_{\mathrm{C}}$, type $^{\mathrm{b}}$ \\
\hline 1 & & 197.6, C & 1 & & 208.3, C \\
\hline 2 & & $56.2, \mathrm{C}$ & 2 & & $56.3, \mathrm{C}$ \\
\hline 3 & & 212.3, C & 3 & & 213.1, C \\
\hline 4 & & $47.3, \mathrm{C}$ & 4 & & $56.9, \mathrm{C}$ \\
\hline $4 a$ & & $166.9, \mathrm{C}$ & & & \\
\hline $4 \mathrm{~b}$ & & 162.6, C & & & \\
\hline 5 & & 107.5, C & 5 & & 208.3, C \\
\hline 6 & & 158.5, C & 6 & & 67.7, C \\
\hline 7 & $6.06 \mathrm{~s}$ & $95.0, \mathrm{CH}$ & 7 & 2.49 brd (17.2), $2.17 \mathrm{~m}$ & $29.5, \mathrm{CH}_{2}$ \\
\hline 8 & & $155.8, \mathrm{C}$ & 8 & 5.31 brs & $116.1, \mathrm{CH}$ \\
\hline $8 \mathrm{a}$ & & 106.9, C & & & \\
\hline 9 & $4.24, \mathrm{t}(5.6)$ & $25.3, \mathrm{CH}$ & 9 & & 136.7, C \\
\hline $9 \mathrm{a}$ & & 114.3, C & & & \\
\hline 10 & $1.36 \mathrm{~s}$ & $24.3, \mathrm{CH}_{3}$ & 10 & $2.13 \mathrm{~m}, 1.98 \mathrm{~m}$ & $30.7, \mathrm{CH}_{2}$ \\
\hline 11 & $1.39 \mathrm{~s}$ & 24.7, $\mathrm{CH}_{3}$ & 11 & $2.31 \mathrm{~m}$ & 34.1, CH \\
\hline 12 & $1.43 \mathrm{~s}$ & 24.7, $\mathrm{CH}_{3}$ & 12 & $1.37 \mathrm{~s}$ & $26.5, \mathrm{CH}_{3}$ \\
\hline \multirow[t]{3}{*}{13} & $1.54 \mathrm{~s}$ & $24.9, \mathrm{CH}_{3}$ & 13 & $1.39 \mathrm{~s}$ & 26.3, $\mathrm{CH}_{3}$ \\
\hline & & & 14 & $1.33 \mathrm{~s}$ & $24.5, \mathrm{CH}_{3}$ \\
\hline & & & 15 & $1.39 \mathrm{~s}$ & $25.8, \mathrm{CH}_{3}$ \\
\hline $1^{\prime}$ & & 206.9, C & $1^{\prime}$ & $1.93 \mathrm{~m}$ & 37.3, $\mathrm{CH}_{2}$ \\
\hline $2^{\prime}$ & $3.09 \mathrm{t}(7.2)$ & 44.6, $\mathrm{CH}_{2}$ & $2^{\prime}$ & $2.03 \mathrm{~m}$ & 26.1, $\mathrm{CH}_{2}$ \\
\hline $3^{\prime}$ & $1.71 \mathrm{~m}$ & 24.4, $\mathrm{CH}_{2}$ & $3^{\prime}$ & 5.03 tq $(7.0,1.4)$ & $124.1, \mathrm{CH}$ \\
\hline $4^{\prime}$ & $1.36 \mathrm{~m}$ & $31.8, \mathrm{CH}_{2}$ & $4^{\prime}$ & & 131.7, C \\
\hline $5^{\prime}$ & $1.36 \mathrm{~m}$ & $22.7, \mathrm{CH}_{2}$ & $5^{\prime}$ & $1.67 \mathrm{~d}(1.4)$ & $25.8, \mathrm{CH}_{3}$ \\
\hline $6^{\prime}$ & $0.91 \mathrm{t}(7.1)$ & $14.2, \mathrm{CH}_{3}$ & $6^{\prime}$ & $1.59 \mathrm{~s}$ & $17.9, \mathrm{CH}_{3}$ \\
\hline $1^{\prime \prime}$ & $1.43 \mathrm{~m}$ & $46.0, \mathrm{CH}_{2}$ & $1^{\prime \prime}$ & $1.39 \mathrm{~m}, 0.78 \mathrm{~m}$ & $39.2, \mathrm{CH}_{2}$ \\
\hline $2^{\prime \prime}$ & $1.35 \mathrm{~m}$ & $25.3, \mathrm{CH}$ & $2^{\prime \prime}$ & $1.63 \mathrm{~m}$ & 25.6, CH \\
\hline $3 "$ & $0.84 \mathrm{~d}(6.0)$ & $23.3, \mathrm{CH}_{3}$ & $3^{\prime \prime}$ & $0.87 \mathrm{~d}(7.0)$ & $24.4, \mathrm{CH}_{3}$ \\
\hline $4^{\prime \prime}$ & $0.87 \mathrm{~d}(6.1)$ & $23.6, \mathrm{CH}_{3}$ & $4^{\prime \prime}$ & $0.85 \mathrm{~d}(7.0)$ & $21.1, \mathrm{CH}_{3}$ \\
\hline
\end{tabular}

${ }^{a}$ Data $(\delta)$ measured at $500 \mathrm{MHz} ; \mathrm{s}=$ singlet, br $\mathrm{s}=$ broad singlet, $\mathrm{d}=$ doublet, $\mathrm{dd}=$ doublet of doublets, $\mathrm{ddd}=$ doublet of doublets of doublets, $\mathrm{dt}=$ doublet of triplets, $\mathrm{m}=$ multiplet. $J$ values are in $\mathrm{Hz}$ and are omitted if the signals overlapped as multiplets. The overlapped signals were assigned from HSQC and HMBC spectra without designating multiplicity.

${ }^{\mathrm{b}}$ Data $(\delta)$ measured at $125 \mathrm{MHz} ; \mathrm{CH}_{3}, \mathrm{CH}_{2}, \mathrm{CH}$, and $\mathrm{C}$ multiplicities were determined by HSQC experiments. 
Compound 2 was isolated as light yellow gum. The protonated molecule peak at $\mathrm{m} / \mathrm{z} 387.2896$ $[\mathrm{M}+\mathrm{H}]^{+}$(calcd for $\mathrm{C}_{25} \mathrm{H}_{39} \mathrm{O}_{3}{ }^{+}, 387.2894$ ) suggested a molecular formula of $\mathrm{C}_{25} \mathrm{H}_{38} \mathrm{O}_{3}$ with 7 degrees of unsaturation. The ${ }^{1} \mathrm{H}$ NMR, ${ }^{13} \mathrm{C}$ NMR and HSQC spectra of 2 showed 3 carbonyl, 5 quaternary, 4 methine, 5 methylene and 8 methyl carbons in the structure. The structure of compound 2 was elucidated to contain a 1,3,5-cyclohexanetrione moiety based on HMBC correlations of $14-$ and $15-\mathrm{Me}\left(\delta_{\mathrm{H}} 1.33\right.$ and 1.39 , each $\left.3 \mathrm{H}, \mathrm{s}\right)$ to $\mathrm{C}-1, \mathrm{C}-2$ and $\mathrm{C}-3\left(\delta_{\mathrm{C}} 208.3,56.3\right.$ and 213.1), of 12- and 13-Me ( $\delta_{\mathrm{H}} 1.37$ and 1.39 , each $\left.3 \mathrm{H}, \mathrm{s}\right)$ to $\mathrm{C}-3, \mathrm{C}-4$ and $\mathrm{C}-5\left(\delta_{\mathrm{C}} 213.1,56.9\right.$, 208.3), and of 13- and 15-Me to C-6 $\left(\delta_{\mathrm{C}} 67.7\right)$. Additional HMBC correlations of $\mathrm{H}-7 \mathrm{a}\left(\delta_{\mathrm{H}} 2.17\right.$, $1 \mathrm{H}, \mathrm{m})$ to $\mathrm{C}-6, \mathrm{C}-8$ and $\mathrm{C}-9\left(\delta_{\mathrm{C}} 67.7,116.1\right.$ and 136.7$) ; \mathrm{H}-7 \mathrm{~b}\left(\delta_{\mathrm{H}} 2.49,1 \mathrm{H}, \mathrm{brd}, J=17.2 \mathrm{~Hz}\right)$ to $\mathrm{C}-1$, of $\mathrm{H}-10 \mathrm{a}\left(\delta_{\mathrm{H}} 2.13,1 \mathrm{H}, \mathrm{m}\right)$ to $\mathrm{C}-6, \mathrm{C}-8$ and $\mathrm{C}-9$, and of $\mathrm{H}-11\left(\delta_{\mathrm{H}} 2.31,1 \mathrm{H}, \mathrm{m}\right)$ to $\mathrm{C}-5$ and $\mathrm{C}-$ 6 indicated a spiro-[5,5]-undec-8-ene skeleton. The presence of an isobutyl group was determined by the cross peaks between $\mathrm{H}-1$ " $\left(\delta_{\mathrm{H}} 0.78\right.$ and 1.39 , each $\left.1 \mathrm{H}, \mathrm{m}\right)$ to $\mathrm{H}-2^{\prime \prime}\left(\delta_{\mathrm{H}} 1.63,1 \mathrm{H}\right.$, $\mathrm{m})$, and of $\mathrm{H}-2$ " to $3 "-\mathrm{Me}\left(\delta_{\mathrm{H}} 0.87,3 \mathrm{H}, \mathrm{d}, J=7.0 \mathrm{~Hz}\right)$ and $4 "-\mathrm{Me}\left(\delta_{\mathrm{H}} 0.87, \mathrm{~d}, J=7.0 \mathrm{~Hz}\right)$ in the ${ }^{1} \mathrm{H}-{ }^{1} \mathrm{H}$ COSY spectra. The placement of the isobutyl group was confirmed by a ${ }^{1} \mathrm{H}-{ }^{1} \mathrm{H}$ COSY correlation of $\mathrm{H}-1$ "a $\left(\delta_{\mathrm{H}} 0.78,1 \mathrm{H}, \mathrm{m}\right)$ to $\mathrm{H}-11$. The presence of the 4-methylpentene unit was established by HMBC data. Key HMBC correlations include $\mathrm{H}-1^{\prime}\left(\delta_{\mathrm{H}} 1.93,2 \mathrm{H}, \mathrm{m}\right)$ to $\mathrm{C}-2^{\prime}\left(\delta_{\mathrm{C}}\right.$ $26.1) ; \mathrm{H}-2^{\prime}\left(\delta_{\mathrm{H}} 2.03,2 \mathrm{H}, \mathrm{m}\right)$ to $\mathrm{C}-3^{\prime}\left(\delta_{\mathrm{C}} 124.1\right) ; 5^{\prime}-\mathrm{Me}\left(\delta_{\mathrm{H}} 1.67,3 \mathrm{H}, \mathrm{d}, J=1.4 \mathrm{~Hz}\right), 6^{\prime}-\mathrm{Me}\left(\delta_{\mathrm{H}}\right.$ $1.59,3 \mathrm{H}, \mathrm{s})$ to $\mathrm{C}-3$ ' and $\mathrm{C}-4{ }^{\prime}\left(\delta_{\mathrm{C}} 131.7\right)$. The 4-methyl-pentene unit was placed at $\mathrm{C}-9$ on the basis of ${ }^{3} J$ HMBC coupling between $\mathrm{H}-1$ and C-10 $\left(\delta_{\mathrm{C}} 30.7\right)$. Compound 2 was a racemate at C11 based on its zero optical rotation, and its structure was thus elucidated as ( \pm )-2,2,4,4tetramethyl-11-isobutyl-9-(4-methyl-3-penten-1-yl)- spiro[5.5]undec-8-ene -1,3,5-trione, and named as $( \pm)$-calliviminone $\mathrm{C}$, based on its similar structure to $( \pm)$-calliviminones $\mathrm{A}$ and $\mathrm{B} .{ }^{17}$ 


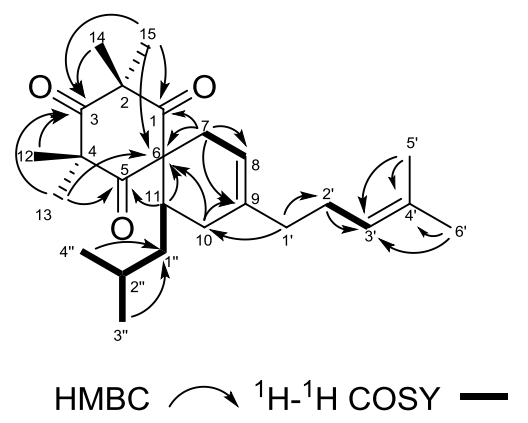

Figure 3. Key HMBC and COSY correlations of compound 2.

Compounds 1-4 showed strong to weak inhibition of the growth of the drug-resistant Dd2 strain of P. falciparum (Table 2), with compound 1 exhibiting the strongest activity with an $\mathrm{IC}_{50}$ of $0.10 \pm$ $0.02 \mu \mathrm{M}$. Acylphloroglucinols with similar structures to compound $\mathbf{1}$ have been reported to show antibacterial activity, ${ }^{18-19}$ and examples of phloroglucinol derivatives as antimalarial agents can be found in the literature, ${ }^{20-21}$ but compound $\mathbf{1}$ is an order of magnitude more potent than tomentosone $\mathrm{A},{ }^{21}$ the closest analog with reported antimalarial activity. Compound $\mathbf{1}$ was also tested for cytotoxicity toward human embryonic kidney cells (HEK) and no inhibition was detected up to $3.125 \mu \mathrm{M}$, and only $58 \%$ inhibition was observed at the highest dose tested (50 $\mu \mathrm{M})$. Compound $\mathbf{1}$ thus appears to be potent and relatively non-toxic antimalarial agent. Compound $\mathbf{2}$ contains the unusual spiro-[5,5]-undec-8-ene skeleton. The first examples of such carbon Diels-Alder adducts between a phloroglucinol and a terpenoid were $( \pm)$-calliviminones $\mathrm{A}$ and $\mathrm{B}$, isolated from Callistemon viminalis. ${ }^{17}$ Compound 2 exhibited moderate antiplasmodial activity $\left(\mathrm{IC}_{50} 3.81 \pm 1.14\right.$ $\mu \mathrm{M})$, which is the first reported antiplasmodial activity of a phloroglucinol with the spiro-[5,5]undec-8-ene skeleton. Compound $\mathbf{2}$ did not show any toxicity to HEK cells up to the highest dose tested $(100 \mu \mathrm{M})$. Betulinic acid (3) showed moderate inhibitory effect on the Dd2 strain of $P$. falciparum, and it has previously been reported to inhibit the 3D7 stain of P. falciparum, a chloroquine-sensitive strain. ${ }^{22}$ Ursolic acid (5) and its 3 -acetate (4) have been reported to be 
antibacterial and antioxidant agents, ${ }^{23}$ but these compounds were inactive against the Dd2 strain of P. falciparum, as previously observed. ${ }^{24}$ Compound 6, 1-(2,4,6-trihydroxyphenyl)-1-hexanone, is a possible biosynthetic precursor of $\mathbf{1}$; it was inactive against $P$. falciparum at the highest dose tested $(90 \mu \mathrm{M})$.

Table 2. Antiplasmodial activity data of compounds $1-6$

\begin{tabular}{|c|c|}
\hline Compound & P. falciparum $\mathrm{Dd} 2$ strain $\mathrm{IC}_{50}(\mu \mathrm{M})$ \\
\hline ( \pm )-Rhodomyrtosone F (1) & $0.10 \pm 0.02$ \\
\hline$( \pm)$-Calliviminone $\mathrm{C}(\mathbf{2})$ & $3.81 \pm 1.14$ \\
\hline Betulinic acid (3) & $3.44 \pm 0.42$ \\
\hline Ursolic acid-3-acetate (4) & $12.09 \pm 0.08$ \\
\hline Ursolic acid (5) & Not active $(>40)$ \\
\hline 1-(2,4,6-Trihydroxyphenyl)-1-hexanone (6) & Not active $(>80)$ \\
\hline
\end{tabular}

\section{Experimental}

\subsection{General experimental procedures}

UV spectra were measured on a Shimadzu UV-1201 spectrophotometer. IR spectra were measured on a MIDAC M-series FTIR spectrometer. NMR spectra were recorded in $\mathrm{CDCl}_{3}$ on a Bruker Avance 500 spectrometer in $\mathrm{CDCl}_{3}$; chemical shifts are given in $\delta(\mathrm{ppm})$, and coupling constants are reported in Hz. Mass spectra were obtained on an Agilent 6220 LC-TOF-MS in the positive ion mode. Optical rotations were recorded on a JASCO P-2000 polarimeter. Open column chromatography was performed using Sephadex LH-20 (I.D $\times$ L $3 \times 50$ cm). Semipreparative HPLC was performed on a Shimadzu LC-10AT instrument with a semipreparative $\mathrm{C}_{18}$ Phenomenex Luna column $(5 \mu \mathrm{m}, 250 \mathrm{X} 10 \mathrm{~mm})$. All isolated compounds were evaluated for purity by HPLC (both UV and ELSD detection) and by NMR before bioactivity assay. Purity of each compound was checked on a Phenomenex Luna $\mathrm{C}_{18}$ column $(5 \mu \mathrm{m}, 250 \times 10 \mathrm{~mm})$ and a Cogent Bidentate $\mathrm{C}_{18}$ column (4 $\mu \mathrm{m}, 76$ X $\left.4.6 \mathrm{~mm}\right)$. 


\subsection{Plant material}

Stem bark from S. glomulifera (Sm.) Nied was collected by Gary J. Ray in Hawaii in June 1998 near Pupukea Road, Pupukea (21.38.39 N, 158.00.54 W). A specimen is on deposit at the New York Botanical Garden under the accession number GR01020c (ID 89558).

\subsection{Extraction and isolation}

Dried, powdered plant material was exhaustively extracted with $\mathrm{MeOH}$ at room temperature to give an extract designated 0040244-10F; a total of $3 \mathrm{~g}$ of this extract was made available to Virginia Tech and $1.2 \mathrm{~g}$ of the material was used in the bioassay guided fractionation. Extract 0040244-10F (1200 mg, $\mathrm{IC}_{50}$ around $1.25 \mu \mathrm{g} / \mathrm{mL}$, tested in antimalarial assay) was suspended in aqueous $\mathrm{MeOH}\left(\mathrm{MeOH}-\mathrm{H}_{2} \mathrm{O}, 9: 1,100 \mathrm{~mL}\right)$ and extracted with hexane $(5 \times 100 \mathrm{~mL}$ portions) to give an active hexane-soluble fraction $\left(288.6 \mathrm{mg}, \mathrm{IC}_{50}<1.25 \mu \mathrm{g} / \mathrm{mL}\right)$. The aqueous fraction was then diluted to $\mathrm{MeOH}-\mathrm{H}_{2} \mathrm{O}, 6: 4(150 \mathrm{~mL})$ and further extracted with $\mathrm{CH}_{2} \mathrm{Cl}_{2}(5 \times 100 \mathrm{~mL}$ portions $)$ to yield the $\mathrm{CH}_{2} \mathrm{Cl}_{2}$-soluble fraction $\left(84.4 \mathrm{mg}, \mathrm{IC}_{50}\right.$ approximately $2.5 \mu \mathrm{g} / \mathrm{mL}$ ) and the aqueous fraction $\left(824.7 \mathrm{mg}, \mathrm{IC}_{50}>10 \mu \mathrm{g} / \mathrm{mL}\right.$ ). The active hexane fraction was then subjected to a size exclusion open column chromatography on Sephadex LH-20 (I.D $\times$ L $3 \times 50 \mathrm{~cm})$ eluted with $\mathrm{CH}_{2} \mathrm{Cl}_{2}: \mathrm{MeOH}$ (1:1). Three fractions (F1-1: $122.7 \mathrm{mg}, \mathrm{F} 1-2: 65.5 \mathrm{mg}, \mathrm{F} 1-3: 99.0 \mathrm{mg}$ ) were collected based on TLC analyses. The active fraction F1-3 ( $\left.\mathrm{IC}_{50}<1.25 \mu \mathrm{g} / \mathrm{mL}\right)$ was further separated by HPLC on a semipreparative $\mathrm{C}_{18}$ column (Phenomenex Luna column, $5 \mu \mathrm{m}, 250$ $\mathrm{X} 10 \mathrm{~mm}$ ) eluted with a solvent gradient from $\mathrm{CH}_{3} \mathrm{OH}: \mathrm{H}_{2} \mathrm{O}, 75: 25$ to $85: 15$ from 0 to $10 \mathrm{~min}$, to 95:5 from 10 to 20 min, ending with $100 \% \mathrm{CH}_{3} \mathrm{OH}$ from 20 to $40 \mathrm{~min}$ at a flow rate of 2.5 $\mathrm{mL} / \mathrm{min}$. This process gave compounds $3\left(4.8 \mathrm{mg}, \mathrm{t}_{\mathrm{R}} 23.5 \mathrm{~min}\right), \mathbf{4}\left(4.2 \mathrm{mg}, \mathrm{t}_{\mathrm{R}} 31 \mathrm{~min}\right)$, and semipure compound $1\left(5.1 \mathrm{mg}, \mathrm{t}_{\mathrm{R}} 26 \mathrm{~min}\right)$ and $2\left(2.0 \mathrm{mg}, \mathrm{t}_{\mathrm{R}} 27.5 \mathrm{~min}\right)$. The collected semi-pure 
compound 1 was then further purified by HPLC on the same column eluted with a solvent gradient from $\mathrm{CH}_{3} \mathrm{CN}: \mathrm{H}_{2} \mathrm{O}, 85: 15$ to $90: 10$ from 0 to $15 \mathrm{~min}$, to 100:0 from 15 to $25 \mathrm{~min}$, ending with $100 \% \mathrm{CH}_{3} \mathrm{CN}$ from 25 to $40 \mathrm{~min}$ at a flow rate of $2.5 \mathrm{~mL} / \mathrm{min}$. This process gave compounds $\mathbf{1}\left(3.6 \mathrm{mg}, \mathrm{t}_{\mathrm{R}} 28 \mathrm{~min}\right)$ and $\mathbf{5}\left(1.3 \mathrm{mg}, \mathrm{t}_{\mathrm{R}} 26 \mathrm{~min}\right)$. Compound $\mathbf{2}$ was also purified by HPLC on the semipreparative $\mathrm{C}_{18}$ column with aqueous acetonitrile as above. This process gave purified compound $\mathbf{2}\left(1.4 \mathrm{mg}, \mathrm{t}_{\mathrm{R}} 36 \mathrm{~min}\right)$.

The moderately active dichloromethane fraction was also subjected to the size exclusion open column using the method described above, to yield three sub-fractions (F2-1: $35.6 \mathrm{mg}$, F2-2: $21.5 \mathrm{mg}$, F2-3: $21.6 \mathrm{mg}$ ). Fraction F2-3 ( $\mathrm{IC}_{50}$ around $2.5 \mu \mathrm{g} / \mathrm{mL}$ ) was separated by HPLC on the Luna $\mathrm{C}_{18}$ column, eluted with a solvent gradient from $\mathrm{CH}_{3} \mathrm{OH}: \mathrm{H}_{2} \mathrm{O}, 60: 40$ to $70: 30$ from 0 to 10 min, to 90:10 from 10 to 30 min, ending with $100 \% \mathrm{CH}_{3} \mathrm{OH}$ from 30 to 40 min at a flow rate of $2.5 \mathrm{~mL} / \mathrm{min}$. This process yielded compound $6\left(2.1 \mathrm{mg}, \mathrm{t}_{\mathrm{R}} 24.5 \mathrm{~min}\right)$ and a small amounts of compounds $\mathbf{1}\left(0.2 \mathrm{mg}, \mathrm{t}_{\mathrm{R}} 33.0 \mathrm{~min}\right)$ and $\mathbf{4}\left(0.4 \mathrm{mg}, \mathrm{t}_{\mathrm{R}} 41.5 \mathrm{~min}\right)$.

\subsection{Antimalarial bioassay}

The effect of each fraction and pure compounds on in vitro parasite growth of Dd2 strain was measured in a $72 \mathrm{~h}$ growth assay in the presence of inhibitor as described previously with minor modifications. ${ }^{25-26}$ Ring stage parasite cultures $(100 \mu \mathrm{L}$ per well, $1 \%$ hematocrit and $1 \%$ parasitaemia) were grown for $72 \mathrm{~h}$ in the presence of increasing concentrations of the inhibitor in a humidified chamber at $37{ }^{\circ} \mathrm{C}$ and low oxygen conditions $\left(5.06 \% \mathrm{CO}_{2}, 4.99 \% \mathrm{O}_{2}\right.$, and $89.95 \%$ $\mathrm{N}_{2}$ ). After $72 \mathrm{~h}$ in culture, parasite viability was determined by DNA quantitation using SYBR Green I as described previously. ${ }^{26}$ The half-maximum inhibitory concentration $\left(\mathrm{IC}_{50}\right)$ values were calculated with KaleidaGraph software using a nonlinear regression curve fitting. $\mathrm{IC}_{50}$ 
values are the average of three independent determinations with each determination in duplicate, and are expressed \pm S.E.M. Artemisinin was used as the positive control with an $\mathrm{IC}_{50}$ of $6.2 \pm 1.2$ $\mathrm{nM}$.

\subsection{In vitro cytotoxicity against HEK293 cells}

Compounds were evaluated for their cytotoxicity against normal cell line HEK293 (Human Embryonic Kidney). Briefly, 10,000 HEK cells per well were plated in a clear-bottom 96 well plate. After allowing the cells to adhere, the media was replaced with $100 \mu \mathrm{L}$ of media containing varying amounts of the test compound and incubated for 24 hours. Later, $10 \mu \mathrm{L}$ of resazurin sodium salt (Sigma) at $0.125 \mathrm{mg} / \mathrm{mL}$ was added to each well and incubated for $2 \mathrm{~h}$. Cell viability was determined by measuring the fluorescence at $585 \mathrm{~nm}$ after excitation at 540 nm.

\section{6. ( \pm )-5-Hexanoyl-6,8-dihydroxy-9-isobutyl-2,2,4,4-tetramethyl-4,9-dihydro-1H-xanthene- 1,3(2H)-dione, ( \pm )-rhodomyrtosone F (1)}

Yellowish gum; $[\alpha]_{D}^{23} 0(c=0.22, \mathrm{MeOH}) ; \mathrm{UV}(\mathrm{MeOH}) \lambda_{\max }(\log \varepsilon) 223$ (3.31), 261 (3.01), 292 (2.51), $333(1.40) \mathrm{nm}$; IR (film) $v_{\max }$ 2935, 2872, 1721, 1629, 1430, 1389, 1108 and $1091 \mathrm{~cm}^{-1}$;

${ }^{1} \mathrm{H}$ and ${ }^{13} \mathrm{C}$ NMR data, see Table 1; positive ion HRESIMS $m / z 457.2591[\mathrm{M}+\mathrm{H}]^{+}$(calculated for $\left.\mathrm{C}_{27} \mathrm{H}_{37} \mathrm{O}_{6}{ }^{+}, 457.2585\right) ; 474.2831\left[\mathrm{M}+\mathrm{NH}_{4}\right]^{+}$(calcd for $\mathrm{C}_{27} \mathrm{H}_{40} \mathrm{NO}_{6}{ }^{+}, 474.2851$ ).

3.7. ( \pm )-11-Isobutyl-2,2,4,4-tetramethyl-9-(4-methylpent-3-en-1-yl)- spiro[5.5]undec-8-ene-1,3, 5-trione, ( \pm )-rhodomyrtosone G (2) 
Yellowish gum; $[\alpha]_{D}^{23} 0(c=0.15, \mathrm{MeOH}) ; \mathrm{UV}(\mathrm{MeOH}) \lambda_{\max }(\log \varepsilon) 214$ (3.53), 297 (2.67); IR (film) $v_{\max } 2357,2335,2146$ and $1699 \mathrm{~cm}^{-1} ;{ }^{1} \mathrm{H}$ and ${ }^{13} \mathrm{C}$ NMR data, see Table 1; positive ion HRESIMS $m / z, 387.2896[\mathrm{M}+\mathrm{H}]^{+}$(calcd for $\mathrm{C}_{25} \mathrm{H}_{39} \mathrm{O}_{3}{ }^{+}, 387.2894$ ).

\section{Acknowledgements}

This project was supported by the National Center for Complementary and Integrative Health (NCCIH) under awards 1 R01 AT008088-01. It was also supported by the National Science Foundation under Grant No. CHE-0619382 for purchase of the Bruker Avance 500 NMR spectrometer and Grant No. CHE- 0722638 for the purchase of the Agilent 6220 mass spectrometer. Funding for this work was also provided in part by the Virginia Agricultural Experiment Station and the Hatch Program of the National Institute of Food and Agriculture, U.S. Department of Agriculture. We thank Mr. B. Bebout for obtaining the mass spectra, and we gratefully acknowledge Gary J. Ray of the New York Botanical Garden for the provision of plant material.

\section{Supplementary data}

Supplementary data associated with this article, consisting of HPLC chromatograms and NMR spectra, can be found, in the online version, at http://dx.doi.org/10.1016/j.bmc.2016.xx.yy.

\section{References and notes}

1. Neghina, R.; Neghina, A. M.; Marincu, I.; Iacobiciu, I. Am. J. Med. Sci. 2010, 340, 492.

2. Wright, A. D.; König, G. M.; Angerhofer, C. K.; Greenidge, P.; Linden, A.;

Desqueyroux-Faúndez, R. J. Nat. Prod. 1996, 59, 710. 
3. 10 facts on malaria. World Health Organization, http://www.who.int/features/factfiles/malaria/en/, accessed February 18, 2016.

4. Snow, R. W.; Guerra, C. A.; Noor, A. M.; Myint, H. Y.; Hay, S. I. Nature 2005, 434, 214.

5. $\quad$ Alker, A. P.; Lim, P.; Sem, R.; Shah, N. K.; Yi, P.; Bouth, D. M.; Tsuyuoka, R.; Maguire, J. D.; Fandeur, T.; Ariey, F. Am. J. Trop. Med. Hyg. 2007, 76, 641.

6. Mehlotra, R. K.; Mattera, G.; Bockarie, M. J.; Maguire, J. D.; Baird, J. K.; Sharma, Y. D.; Alifrangis, M.; Dorsey, G.; Rosenthal, P. J.; Fryauff, D. J. Antimicrob. Agents Chemother. 2008, 52, 2212.

7. Drug Resistance in the Malaria-Endemic World. http://www.cdc.gov/malaria/malaria_worldwide/reduction/drug resistance.html, accessed October 30, 2015.

8. Dondorp, A. M.; Nosten, F.; Yi, P.; Das, D.; Phyo, A. P.; Tarning, J.; Lwin, K. M.; Ariey, F.; Hanpithakpong, W.; Lee, S. J.; Ringwald, P.; Silamut, K.; Imwong, M.; Chotivanich, K.; Lim, P.; Herdman, T.; An, S. S.; Yeung, S.; Singhasivanon, P.; Day, N. P. J.; Lindegardh, N.; Socheat, D.; White, N. J. New Engl. J. Med. 2009, 361, 455.

9. $\quad$ Setzer, W. N.; Setzer, M. C.; Bates, R. B.; Jackes, B. R. Planta Med. 2000, 66, 176.

10. Ayatollahi, A. M.; Ghanadian, M.; Afsharypour, S.; Abdella, O. M.; Mirzai, M.; Askari, G. Iran. J. Pharm. Res. 2011, 10, 287.

11. Gnoatto, S. C.; Dassonville-Klimpt, A.; Da Nascimento, S.; Galéra, P.; Boumediene, K.; Gosmann, G.; Sonnet, P.; Moslemi, S. Eur. J. Med. Chem. 2008, 43, 1865.

12. Frišcic, T.; Drab, D. M.; MacGillivray, L. R. Org. Lett. 2004, 6, 4647.

13. Appendino, G.; Bianchi, F.; Minassi, A.; Sterner, O.; Ballero, M.; Gibbons, S. J. Nat. Prod. 2002, 65, 334. 
14. Hiranrat, A.; Mahabusarakam, W. Tetrahedron 2008, 64, 11193.

15. Dachriyamas; Salni; Sargent, M. D.; Skelton, B. W.; Soediro, I.; Sutisna, M.; White, A. H.; Yulinah, E. Aust. J. Chem. 2002, 55, 229.

16. Wang, C.; Yang, J.; Zhao, P.; Zhou, Q.; Mei, Z.; Yang, G.; Yang, X.; Feng, Y. Bioorg. Med. Chem. Lett. 2014, 24, 3096.

17. Wu, L.; Luo, J.; Zhang, Y.; Zhu, M.; Wang, X.; Luo, J.; Yang, M.; Yu, B.; Yao, H.; Dai, Y. Tetrahedron Lett. 2015, 56, 229.

18. Rattanaburi, S.; Mahabusarakam, W.; Phongpaichit, S.; Carroll, A. R. Tetrahedron 2013, 69, 6070.

19. Saising, J.; Götz, F.; Dube, L.; Ziebandt, A. K.; Voravuthikunchai, S. P. Ann. Microbiol. 2015, 65, 659 .

20. Harinantenaina, L.; Bowman, J. D.; Brodie, P. J.; Slebodnick, C.; Callmander, M. W.; Rakotobe, E.; Randrianaivo, R.; Rasamison, V. E.; Gorka, A.; Roepe, P. D.; Cassera, M. B.; Kingston, D. G. I. J. Nat. Prod. 2013, 76, 388.

21. Hiranrat, A.; Mahabusarakam, W.; Carroll, A. R.; Duffy, S.; Avery, V. M. J. Org. Chem. 2011, 77, 680 .

22. Ziegler, H. L.; Franzyk, H.; Sairafianpour, M.; Tabatabai, M.; Tehrani, M. D.; Bagherzadeh, K.; Hägerstrand, H.; Stærk, D.; Jaroszewski, J. W. Bioorg. Med. Chem. 2004, 12, 119.

23. do Nascimento, P. G.; Lemos, T. L.; Bizerra, A.; Arriaga, Â.; Ferreira, D. A.; Santiago, G. M.; Braz-Filho, R.; Costa, J. G. M. Molecules 2014, 19, 1317.

24. Innocente, A. M.; Silva, G. N.; Cruz, L. N.; Moraes, M. S.; Nakabashi, M.; Sonnet, P.; Gosmann, G.; Garcia, C. R.; Gnoatto, S. C. Molecules 2012, 17, 12003. 
25. Bennett, T. N.; Paguio, M.; Gligorijevic, B.; Seudieu, C.; Kosar, A. D.; Davidson, E.;

Roepe, P. D. Antimicrob. Agents Chemother. 2004, 48, 1807.

26. Smilkstein, M.; Sriwilaijaroen, N.; Kelly, J. X.; Wilairat, P.; Riscoe, M. Antimicrob. Agents Chemother. 2004, 48, 1803.

\section{Graphical Abstract}

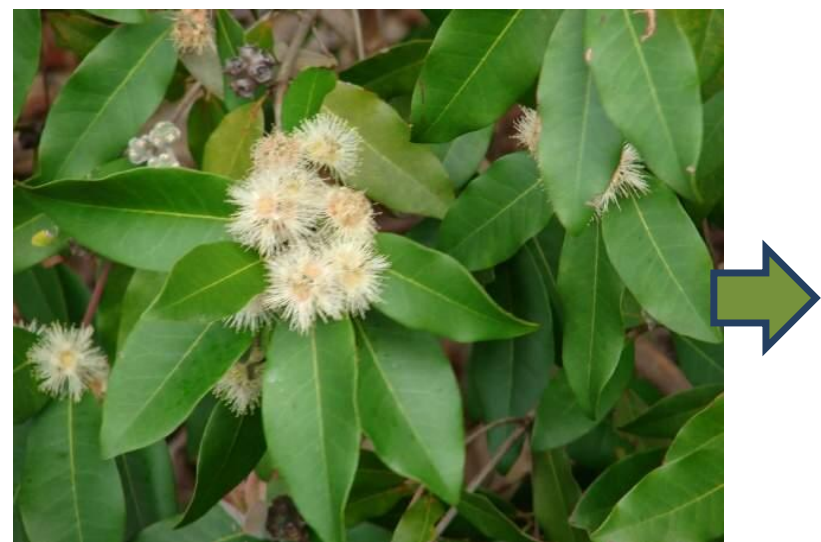

Syncarpia glomulifera

Flowers and leaves at Kahakapao Reservoir Haleakala Ranch, Maui - Credit: Forest and Kim Starr - Plants of Hawaii - Image licensed under a Creative Commons Attribution 3.0 License, permitting sharing and adaptation with attribution<smiles>CCCCCC(=O)c1c(O)c(O)c(O)c2c1OC1=C(C(=O)C(C)(C)C(=O)C(C)(C)C1CC(C)C)C2C</smiles>

1. ( \pm )-Rhodomyrtosone F

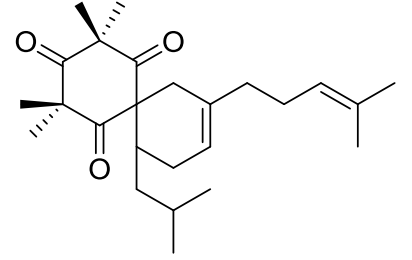

2. ( \pm )-Calliviminone $\mathrm{C}$
P. falciparum Dd2 strain $\mathrm{IC}_{50}(\mu \mathrm{M})$

Compound $1 \quad 0.10 \pm 0.02$

Compound $2 \quad 3.81 \pm 1.14$ 